From Massachusetts General Hospital, Boston, MA; and the University of Turin, Turin, Italy.

Submitted May 31, 2010; accepted September 1, 2010; published online ahead of print at www.jco.org on November 1, 2010

Editorial support was funded by sanofiaventis, US.

Authors' disclosures of potential conflicts of interest and author contributions are found at the end of this article.

Corresponding author: Panos M. Fidias, MD, Center for Thoracic Cancers, Massachusetts General Hospital, 55 Fruit St, Boston, MA 02114; e-mail: pfidias2@partners.org.

(C) 2010 by American Society of Clinical Oncology

0732-183X/10/2834-5116/\$20.00

DOI: $10.1200 / J C O .2010 .30 .7074$

\title{
Strategies for Prolonged Therapy in Patients With Advanced Non-Small-Cell Lung Cancer
}

Panos Fidias and Silvia Novello

$$
\begin{array}{llllllll}
\text { A } & \text { B } & \text { S } & \text { T } & \text { R } & \text { A } & \text { C } & \text { T }
\end{array}
$$

\section{Purpose}

A key challenge in the treatment of advanced non-small-cell lung cancer (NSCLC) is improving outcomes for patients who have achieved at least stable disease after standard first-line therapy. Although current guidelines recommend a maximum of six cycles of first-line therapy, even in responding patients, recent trials have shown benefit with maintenance therapy.

\section{Methods}

We reviewed the English literature for randomized controlled trials on prolonged therapy for NSCLC conducted between January 1999 and January 2010. The search was supplemented by a review of abstracts presented at the American Society of Clinical Oncology annual meetings (2004 to 2010), the World Lung Cancer Conference (2007 to 2009), and the 2009 Joint European CanCer Organisation-European Society for Medical Oncology conference.

\section{Results}

Several alternative strategies for prolongation of chemotherapy have been tested: these can be broadly categorized as continuation (prolongation of the first-line regimen until disease progression, unacceptable toxicity, or administration of a predefined greater number of treatment cycles), switch-maintenance (administration of an active agent immediately after completion of the initial course of chemotherapy), and continuation-maintenance (ongoing administration of a lower intensity version of the first-line chemotherapy regimen). These approaches differ from traditional second line, which is defined as treatment administered after documented clinical progression subsequent to first-line therapy.

\section{Conclusion}

There are no data to support continuation chemotherapy in advanced NSCLC. Switch-maintenance trials with erlotinib and pemetrexed have demonstrated an improvement in overall survival. Thus far, continuation-maintenance has shown an improvement in progression-free survival, without an overall survival advantage.

\section{J Clin Oncol 28:5116-5123. (C) 2010 by American Society of Clinical Oncology}

\section{INTRODUCTION}

An estimated 215,000 new instances of lung cancer were diagnosed in the United States in $2008,{ }^{1}$ with most of these cases $(>80 \%)$ categorized as nonsmall-cell lung cancer (NSCLC). The majority of patients with NSCLC present with locally advanced $(\approx 35 \%)$ or metastatic disease $(\approx 40 \%),{ }^{1}$ and in this palliative setting balancing efficacy with toxicity is of the utmost importance.

Platinum-based doublets are the mainstay of standard chemotherapy for patients with good performance status who have advanced NSCLC.,3 Adding targeted agents, such as bevacizumab ${ }^{4}$ or cetuximab, ${ }^{5}$ to standard chemotherapy can, in selected groups of patients, increase the overall survival (OS).
The purpose of this article is to review recent studies that have evaluated strategies aimed at prolonging the duration of chemotherapy in eligible patients with NSCLC, and to discuss the advantages/ disadvantages and current clinical objectives of the different approaches.

\section{METHODS}

Information for this review was derived from a search of the PubMed database using the following search strategy: (NSCLC AND [advanced OR metastatic]) AND (sequential OR prolonged OR strategy OR second-line OR schedule OR maintenance). The search was restricted to randomized controlled trials (RCT) published in English between January 1999 and January 2010. Primary citations were hand searched and relevant secondary publications identified. The search was supplemented by a review of 
abstracts presented at the American Society of Clinical Oncology (ASCO) annual meeting (2004 to 2010), the World Lung Cancer Conference (2007 to 2009), and the 2009 Joint European CanCer Organisation-European Society for Medical Oncology conference.

\section{Strategies to Optimize Therapy}

The optimal duration of chemotherapy in advanced NSCLC was the subject of a recent meta-analysis. ${ }^{6}$ The analysis covered 13 RCTs and found that continuing chemotherapy beyond 3 or 4 cycles significantly increased progression-free survival (PFS) with a hazard ratio (HR) of 0.75 (95\% CI, 0.69 to $0.81 ; P<.0001)$. Improvement in OS was associated with a statistically significant, but marginal, $\mathrm{HR}$ of 0.92 ( $95 \% \mathrm{CI}, 0.86$ to 0.99 ; $P=.03$ ). Adverse events were also more common with longer-duration therapy, although quality of life (QoL) data were not available for six of the studies. Although this study evaluated a wide variety of prolonged treatment strategies, the authors found no significant differences based on the specific strategy chosen. The same conclusion was reached in a meta-analysis performed by Lima et al. ${ }^{7}$ This study targeted seven RCTs of a defined number of chemotherapy cycles versus continuing treatment until disease progression or a higher number of cycles. Treatment with more than 4 cycles was associated with an improved PFS (HR, $0.75 ; P<.001)$ in the absence of an OS benefit (HR, 0.97; $P=.65)$. Current guidelines from the National Comprehensive Cancer Network, ASCO, and the European Society of Medical Oncologists all recommend up to a maximum of 6 and a minimum of 4 cycles of first-line platinum-based doublet chemotherapy for responding patients or those with stable disease. ${ }^{2,3}$

A key challenge is to improve the outcome of eligible patients who have received adequate first-line therapy and have achieved at least stable disease. Before discussing the options, it is worth considering what proportion of patients actually receives second-line therapy. Evidence from recent major clinical trials, such as the Eastern Cooperative Oncology Group (ECOG) 4599 study, ${ }^{4}$ the trial comparing cisplatin/pemetrexed with cisplatin/gemcitabine, ${ }^{8}$ and First-Line Erbitux in Lung Cancer (FLEX $)^{5}$ suggest this figure is approximately $50 \%$ to $60 \%$ of patients receiving first-line therapy.

Although several approaches have been investigated for the prolongation of therapy duration in patients with advanced NSCLC, there are currently no formal or well-accepted definitions for the various strategies used. Most investigators accept the term continuation therapy as the prolongation of the first-line chemotherapy. For the purpose of this review, we have used the definitions given by National Comprehensive Cancer Network for maintenance treatment (continuation-maintenance and switch-maintenance).

\section{Continuation Therapy}

Continuation in the context of strategies for prolonging therapy in advanced NSCLC involves continuing the first-line regimen until disease progression, unacceptable toxicity, or administration of a predefined greater number of treatment cycles.

A number of studies reported that continuation of initial chemotherapy beyond 4 to 6 cycles is not associated with improved response rate or survival, even in patients with stable or responsive disease. The first study was the randomized trial conducted by Smith et al. ${ }^{9}$ In this trial, patients were randomly assigned to either 3 or 6 cycles of mitomycin, vinblastine, and cisplatin. There were no differences between the two regimens in terms of median survival ( $6 v 7$ months), 1-year survival (22\% v25\%), or duration of symptom relief ( 4.5 months in both groups), while some QoL measures were better in the 3 -cycle arm. While more than $70 \%$ of the patients completed 3 cycles of therapy, fewer than one third were able to receive 6 cycles. The study conducted by Socinski et $\mathrm{al}^{10}$ compared a regimen of carboplatin and paclitaxel given every 3 weeks for either 4 cycles (arm A) or continuously until progression (arm B). Patients received second-line treatment (after the scheduled 4 cycles in arm A or at progression in arm B) comprising weekly paclitaxel 80 $\mathrm{mg} / \mathrm{m}^{2}$. There were no significant differences between the two arms in terms of OS (6.6 $v 8.5$ months; $P=.63$ ) or QoL, as measured using the Functional Assessment of Cancer Therapy-Lung instrument. Moreover, clinically relevant neuropathy was much more common in patients receiving prolonged paclitaxel $(27 \% v 14 \%)$. The lack of a significant difference in survival between the study arms was evident both in the overall population and when comparing subgroups of patients who had received at least 4 treatment cycles.
In the other study, von Plessen et al evaluated carboplatin (area under the curve, 4 by Chatelut, day 1) plus vinorelbine $\left(25 \mathrm{mg} / \mathrm{m}^{2}\right.$, days 1 and 8$)$ every 3 weeks given for either 3 or 6 cycles. ${ }^{11}$ There was no significant difference in OS ( 28 weeks [ 3 cycles] $v 32$ weeks [ 6 cycles]; $P=.75$ ) or PFS ( 16 weeks [ 3 cycles] $v$ 21 weeks [6 cycles]; $P=.21$ ). In addition, QoL assessment up to 26 weeks (using the European Organisation for the Research and Treatment of Cancer Quality of Life Questionnaire 30 or Quality of Life Questionnaire LC13 [Lung Cancer module]) was not significantly different between the two groups, in terms of global QoL, pain, and fatigue.

Although the results of these studies were indicative of a lack of benefit with continuation chemotherapy in patients with advanced NSCLC, it is important to note that the majority of patients randomly assigned to longer courses of chemotherapy did not receive the planned number of cycles because of toxicity or disease progression. In the study by Socinski, only $57 \%$ of patients in arm A completed the scheduled 4 cycles of therapy, while in the continuous treatment arm, the median number of cycles administered was 4 (range, 0 to 19), with $42 \%$ and $18 \%$ of patients receiving more than 4 and $\geq 8$ cycles, respectively. In the study by von Plessen, $78 \%$ to $79 \%$ of patients across the study completed 3 cycles of therapy; however, only $54 \%$ of patients assigned to the longer regimen completed 6 cycles of therapy.

\section{Continuation-Maintenance Therapy}

Ongoing administration of a lower intensity version of the first-line regimen can be termed continuation-maintenance therapy. Because it uses a less intensive regimen, maintenance therapy could facilitate more consistent delivery of chemotherapy compared with continuation therapy.

In a study conducted by Belani et $\mathrm{al}^{12}$, patients were initially randomly assigned to one of three paclitaxel/carboplatin regimens(Tables 1 and 2). ${ }^{12-15}$ Patients who responded after 4 cycles were randomly assigned to either weekly low-dose paclitaxel or to observation only. Although the study was not powered to compare outcomes during the maintenance phase, both time to progression ( $38 v 29$ weeks) and OS (75 v60 weeks) were longer in patients who received maintenance paclitaxel. Another trial evaluated maintenance gemcitabine versus best supportive care (BSC) after induction treatment with 4 cycles of gemcitabine and cisplatin. ${ }^{13}$ Patients with responsive or stable disease were randomly assigned to maintenance gemcitabine or to BSC only. Time to progression, which was the primary end point, was significantly longer for patients who received maintenance therapy, both throughout the entire study period ( $6.6 v 5$ months; $P<.001)$ and during the randomization period $(3.6 v$ 2 months). There was also a trend toward longer OS throughout the entire study in the maintenance gemcitabine group. The study noted no significant differences in QoL between the two arms.

Two additional studies with maintenance gemcitabine were recently reported. ${ }^{14,15}$ In the first study, patients with stable or responsive disease were randomly assigned to either gemcitabine with BSC or BSC alone. The study closed after 6 years due to slow accrual, at which point 179 of the 238 planned events had occurred. Moreover, a large portion of the patients in both cohorts had a performance status (PS) of 2 to 3 . Not surprisingly, the rate of secondline therapy for the control group was very low, at $17 \%$. There was no difference in PFS, calculated from first-line therapy (maintenance, 7.4 months; BSC, 7.7 months), or OS (maintenance, 8 months; BSC 9.3 months). It appears that poor PS patients may not be good candidates for ongoing chemotherapy. The second study, however, showed a strong PFS benefit for those patients, who continued gemcitabine after four cycles of cisplatin and gemcitabine induction. The design of this French study (Intergroupe Francophone de Cancerologie Thoracique-Groupe Francais de Pneumo-Cancerologie [IFCT-GFPC] 0502) randomly assigned patients to observation or two different maintenance regimens, gemcitabine, or erlotinib. Moreover, it mandated second-line therapy for all patients with pemetrexed. Since the study was designed before the interaction of pemetrexed with histology was known, $19 \%$ of patients in the observation group had squamous cell histology. Independently assessed PFS was longer in the gemcitabine arm $(3.8 v 1.9$ months; HR, $0.55 ; P<.001)$. OS was a secondary end point and with $69.6 \%$ of events having occurred, the HR of the comparison between gemcitabine and observation is 0.86 (95\% CI, 0.66 to 1.12 ). Impressively, $81.9 \%$ of patients in the observation arm received US Food and Drug Administration-approved second-line therapy, which is the highest salvage therapy rate reported in maintenance trials and balances much 
Table 1. Patient Characteristics in Trials of Continuation-Maintenance Therapy

\begin{tabular}{|c|c|c|c|c|c|c|c|c|}
\hline \multirow[b]{2}{*}{ Characteristic } & \multicolumn{8}{|c|}{ Study and Agent } \\
\hline & \multicolumn{2}{|c|}{$\begin{array}{c}\text { Belani }(2003)^{12} \\
\text { Paclitaxel }\end{array}$} & \multicolumn{2}{|c|}{$\begin{array}{c}\text { Brodowicz }(2006)^{13} \\
\text { Gemcitabine }\end{array}$} & \multicolumn{2}{|c|}{$\begin{array}{c}\text { Belani et al }(2010)^{14} \\
\text { Gemcitabine }\end{array}$} & \multicolumn{2}{|c|}{$\begin{array}{c}\text { Pérol et al }(2010)^{15} \\
\text { Gemcitabine }\end{array}$} \\
\hline Maintenance & Yes & No & Yes & No & Yes & No & Yes & No \\
\hline No. of patients & 65 & 65 & 138 & 68 & 128 & 127 & 154 & 155 \\
\hline Age, years & 66 & 65 & 58 & 56 & 67.2 & 67.5 & 57.9 & 59.8 \\
\hline Male, \% & 63 & 62 & 70.2 & 79.4 & 60 & 67 & 73 & 73 \\
\hline Performance status $0-1, \%$ & 91 & 92 & $47.8^{*}$ & $48.5^{*}$ & 44 & 43 & 94 & 97 \\
\hline Stage IV, \% & 72 & 78 & 72.5 & 73.5 & 78 & 91 & 91 & 91 \\
\hline Adenocarcinoma, \% & NR & NR & 44.9 & 39.7 & NR & NR & 66 & 67 \\
\hline Squamous, \% & NR & NR & 42 & 38.2 & NR & NR & 22 & 19 \\
\hline Never smokers, \% & NR & NR & NR & NR & NR & NR & 38 & 38 \\
\hline
\end{tabular}

Abbreviation: NR, not recorded.

*Percentage of patients with Karnofsky performance status $>80$.

better the two arms in terms of overall therapy delivered. Unfortunately, with about 150 patients randomly assigned in each arm, this trial may not have the power to detect any clinically meaningful survival differences.

Despite complete lack of randomized data, maintenance therapy with bevacizumab or cetuximab is currently recommended after induction with antibody containing chemotherapy, based on the design of ECOG 4599 and FLEX. ${ }^{2}$

\section{Switch-Maintenance Therapy}

Switch-maintenance therapy involves the administration of an agent with established activity in advanced NSCLC, immediately after completion of the initial course of chemotherapy. Although any active agent against NSCLC could be considered for maintenance therapy, switch-maintenance trials thus far have only evaluated approved second-line agents (docetaxel, ${ }^{16,17}$ erlotinib, ${ }^{18}$ and pemetrexed ${ }^{19}$ ).

Preclinical and clinical data have shown that taxanes, such as docetaxel, are active in platinum-resistant NSCLC, ${ }^{20,21}$ indicating that the delivery of taxanes after platinum-based induction therapy using a switch-maintenance strategy may be a viable option. A phase III study involving 566 patients with stage IIIB/IV NSCLC evaluated this approach directly (Tables 3 and 4). ${ }^{15,22-26}$ The study evaluated the relative efficacy of docetaxel given either immediately after first-line therapy or at disease progression. This is the only study to date that has examined directly the issue of chemotherapy timing, since both groups were scheduled to receive the same regimen. Of the original cohort, 309 patients completed first-line treatment consisting of 4 cycles of carboplatin and gemcitabine and were randomly assigned to immediate or delayed docetaxel for a maximum of 6 cycles. Median PFS was significantly longer in the immediate versus the delayed docetaxel group ( $5.7 v 2.7$ months; $P=.0001)$. There was also a nonsignificant trend toward longer OS in the immediate docetaxel group (12.3 $v 9.7$ months; $P=.0853)$. A significant proportion of patients in the delayed treatment arm never received docetaxel (although $63 \%$ were able to receive therapy), compared to the immediate arm, where almost all patients did. The major reason for not receiving chemotherapy in the delayed arm was significant symptomatic deterioration by the time disease progression occurred. Analysis of patients who actually received docetaxel revealed that OS was identical in both arms of the study (12.5 months), possibly indicating that the trend toward improved OS was because more patients in the immediate group were able to receive docetaxel treatment. Toxicity profiles were generally similar between the arms. Comparisons of QoL, measured during chemotherapy for patients in the immediate arm and during observation in the delayed arm, showed no significant differences.

The potential utility of early second-line therapy with the antifolate pemetrexed was investigated in a phase III trial. ${ }^{23}$ A total of 663 patients who had not progressed after 4 cycles of platinum-based induction therapy

\begin{tabular}{|c|c|c|c|c|c|c|}
\hline Study & Year & Induction Therapy & Maintenance Therapy & $\begin{array}{l}\text { Median } \\
\text { TTP/PFS* }\end{array}$ & Median OS* & Main Grade 3/4 Toxicities \\
\hline Belani et al ${ }^{12}$ & 2003 & $\begin{array}{l}\text { Paclitaxel/carboplatin (random } \\
\text { assignment to one of } \\
\text { three regimens) }\end{array}$ & $\begin{array}{l}\text { Paclitaxel } 70 \mathrm{mg} / \mathrm{m}^{2} \text { weekly } \\
\quad \text { for } 3 \text { of } 4 \text { weeks } \\
\text { Observation }\end{array}$ & $\begin{array}{l}38 \text { weeks } \\
29 \text { weeks }\end{array}$ & $\begin{array}{l}75 \text { weeks } \\
60 \text { weeks }\end{array}$ & $\begin{array}{l}\text { All grade } 3 / 4 \text { toxicities: } 45 \% \text { for } \\
\text { paclitaxel maintenance }\end{array}$ \\
\hline $\begin{array}{l}\text { Brodowicz } \\
\quad \text { et } \mathrm{al}^{13}\end{array}$ & 2006 & $\begin{array}{l}\text { Gemcitabine } 1,250 \mathrm{mg} / \mathrm{m}^{2} \text { on } \\
\text { days } 1 \text { and } 8 \text { plus cisplatin } \\
80 \mathrm{mg} / \mathrm{m}^{2} \text { on day } 1 \text { every } \\
3 \text { weeks for up to } 4 \text { cycles }\end{array}$ & $\begin{array}{l}\text { Gemcitabine } 1,250 \mathrm{mg} / \mathrm{m}^{2} \\
\text { days } 1 \text { and } 8 \text { plus BSC } \\
\text { BSC }\end{array}$ & $\begin{array}{l}6.6 \text { months } \\
5.0 \text { months; } \\
P<.001\end{array}$ & $\begin{array}{l}13.0 \text { months } \\
11.0 \text { months }\end{array}$ & $\begin{array}{l}\text { Maintenance gemcitabine: ANC, } 14.9 \% \text {; } \\
\text { PLT, } 1.7 \% \text {; blood transfusion: } 20.0 \% \\
\text { (gemcitabine), 6.3\% (BSC) }\end{array}$ \\
\hline Belani et $\mathrm{al}^{14}$ & 2010 & $\begin{array}{l}\text { Carboplatin AUC } 5 \text { on day } 1 ; \\
\text { gemcitabine } 1,000 \mathrm{mg} / \mathrm{m}^{2} \\
\text { on days } 1,8 \times 4 \text { cycles }\end{array}$ & $\begin{array}{l}\text { Gemcitabine } 1,000 \mathrm{mg} / \mathrm{m}^{2} \\
\text { on days } 1 \text { and } 8 \text { plus } \\
\text { BSC } \\
\text { BSC }\end{array}$ & $\begin{array}{l}7.4 \text { months; } \\
P=.575 \\
7.7 \text { months }\end{array}$ & $\begin{array}{l}8.0 \text { months; } \\
P=.838 \\
9.3 \text { months }\end{array}$ & $\begin{array}{l}\text { ANC: } 15 \% \text { chemo, } 2 \% \text { BSC PLT: } 9 \% \\
\text { chemo, } 4 \% \text { BSC fatigue: } 5 \% \text { chemo- } \\
\text { therapy, } 2 \% \text { BSC }\end{array}$ \\
\hline Pérol et al ${ }^{15}$ & 2010 & $\begin{array}{l}\text { Cisplatin } 80 \mathrm{mg} / \mathrm{m}^{2} \text { on day } 1 \\
\text { gemcitabine } 1,250 \mathrm{mg} / \mathrm{m}^{2} \\
\text { on days } 1,8 \times 4 \mathrm{cycles}\end{array}$ & $\begin{array}{l}\text { Gemcitabine } 1,250 \mathrm{mg} / \mathrm{m}^{2} \\
\text { days } 1 \text { and } 8 \text { plus BSC } \\
\text { Observation }\end{array}$ & $\begin{array}{l}3.8 \text { months; } \\
\quad P<.001 \\
1.9 \text { months }\end{array}$ & NR & $\begin{array}{l}\text { At least } 1 \text { grade } 3 / 4 \mathrm{AE} \text { : chemotherapy } \\
27.9 \% \text {, observation } 2.6 \%\end{array}$ \\
\hline
\end{tabular}




\begin{tabular}{|c|c|c|c|c|c|c|c|c|c|c|}
\hline \multirow{3}{*}{$\frac{\text { Characteristic }}{\text { Maintenance }}$} & \multicolumn{10}{|c|}{ Study and Agent } \\
\hline & \multicolumn{2}{|c|}{$\begin{array}{l}\text { Fidias et al } \\
(2008)^{22} \\
\text { Docetaxel }\end{array}$} & \multicolumn{2}{|c|}{$\begin{array}{c}\text { Ciuleanu et al } \\
(2009)^{23} \\
\text { Pemetrexed }\end{array}$} & \multicolumn{2}{|c|}{$\begin{array}{l}\text { Cappuzzo et al } \\
(2009)^{24} \\
\text { Erlotinib }\end{array}$} & \multicolumn{2}{|c|}{$\begin{array}{l}\text { Miller et al } \\
(2009)^{25} \\
\text { Erlotinib }\end{array}$} & \multicolumn{2}{|c|}{$\begin{array}{l}\text { Pérol et al } \\
(2010)^{15} \\
\text { Erlotinib }\end{array}$} \\
\hline & Yes & No & Yes & No & Yes & No & Yes & No & Yes & No \\
\hline No. of patients & 153 & 156 & 441 & 222 & 438 & 451 & 370 & 373 & 155 & 155 \\
\hline Age, years & 65.4 & 65.5 & 60.6 & 60.4 & 60 & 60 & 64 & 64 & 56.4 & 59.8 \\
\hline Male, \% & 62.1 & 62.2 & 73 & 73 & 73 & 75 & 52.2 & 52.3 & 73 & 73 \\
\hline Performance status $0-1, \%$ & 94.1 & 89.7 & 100 & 100 & 100 & 100 & 100 & 100 & 94 & 97 \\
\hline Stage IV, \% & 82.4 & 83.3 & 82 & 79 & 74 & 76 & 85.6 & 83.3 & 93 & 91 \\
\hline Adenocarcinoma, \% & 54.9 & 46.8 & 50 & 48 & 47 & 44 & 81.3 & 82.5 & 63 & 67 \\
\hline Squamous, \% & 16.3 & 18.6 & 26 & 30 & 38 & 43 & $3^{*}$ & $1.6^{*}$ & 17 & 19 \\
\hline Never smokers, \% & NR & NR & 26 & 28 & 18 & 17 & 16.5 & 17.7 & 38 & 38 \\
\hline
\end{tabular}

were randomly assigned in a 2:1 ratio to receive pemetrexed plus BSC or placebo plus BSC. Pemetrexed was not used in the induction regimens. Patient characteristics were well-balanced between the two groups. Maintenance therapy significantly improved the independently assessed PFS (4.0 $v 2.0$ months; HR, $0.60 ; P<.001)$ and OS (13.4 $v 10.6$ months; HR, $0.79 ; P=.012)$ compared with placebo. The clinical benefit of pemetrexed was only evident in patients with nonsquamous histology (PFS, $4.4 v 1.8$ months; HR, 0.47; $P<.001$; OS, 15.5 v 10.3 months; HR, 0.70; $P=.002$ ), while a predefined analysis in patients with squamous cell histology showed no improvement in any survival end point (PFS: $2.4 v 2.5$ months; HR, 1.03; OS: $9.9 v 10.8$ months, HR, 1.07). A large portion of patients assigned to placebo received second-line therapy (67\%), although only $18 \%$ actually received pemetrexed. Other active agents included docetaxel (29\%), erlotinib (21\%), and gefitinib (10\%).

\begin{tabular}{|c|c|c|c|c|c|c|c|}
\hline Study & Year & Induction & Intervention & $\begin{array}{l}\text { Median PFS } \\
\text { (months) }\end{array}$ & $\begin{array}{l}\text { Median OS } \\
\text { (months) }\end{array}$ & Main Grade 3/4 Toxicities & QoL \\
\hline \multirow[t]{2}{*}{ Fidias et $\mathrm{al}^{22}$} & \multirow[t]{2}{*}{2008} & \multirow[t]{2}{*}{ CG $\times 4$ cycles } & $\begin{array}{l}\text { Immediate docetaxel } \\
75 \mathrm{mg} / \mathrm{m}^{2} \text { every } 3 \\
\text { weeks (maximum of } \\
6 \text { cycles) }\end{array}$ & 5.7 & 12.3 & $\begin{array}{l}\text { Neutropenia, } 27.6 \% \\
\text { febrile neutropenia, } 3.5 \% \\
\text { fatigue, } 9.7 \%\end{array}$ & \multirow[t]{2}{*}{$\begin{array}{c}\text { No significant } \\
\text { difference }\end{array}$} \\
\hline & & & $\begin{array}{l}\text { Delayed docetaxel } 75 \\
\mathrm{mg} / \mathrm{m}^{2} \text { every } 3 \\
\text { weeks at first } \\
\text { evidence of PD }\end{array}$ & $P \stackrel{2.7}{<}=.001$ & $\begin{array}{c}9.7 \\
P=.0853\end{array}$ & $\begin{array}{l}\text { Neutropenia, } 28.6 \% \\
\text { febrile neutropenia, } 2 \% \\
\text { fatigue, } 4.1 \%\end{array}$ & \\
\hline \multirow[t]{2}{*}{ Ciuleanu et $a^{23}$} & \multirow[t]{2}{*}{2009} & \multirow[t]{2}{*}{$\begin{array}{l}\text { Platinum-based } \\
\text { doublet } \times 4 \\
\text { cycles }\end{array}$} & $\begin{array}{l}\text { Pemetrexed } 500 \mathrm{mg} / \\
\mathrm{m}^{2} \text { every } 3 \text { weeks }+ \\
\text { BSC }\end{array}$ & 4.0 & 13.4 & $\begin{array}{l}\text { Total, } 16 \% \\
\text { fatigue, } 5 \% \\
\text { anemia, } 3 \% \\
\text { infection, } 2 \%\end{array}$ & \multirow[t]{2}{*}{$\begin{array}{l}\text { Favored pemetrexed } \\
\text { for control of pain } \\
\text { and hemoptysis }\end{array}$} \\
\hline & & & BSC & $P \stackrel{2.0 ;}{<.001}$ & $\begin{array}{c}10.6 \\
P=.012\end{array}$ & $\begin{array}{l}\text { Total, } 4 \% \\
\text { fatigue, }<1 \% \\
\text { anemia, }<1 \% \\
\text { infection, } 0 \%\end{array}$ & \\
\hline \multirow[t]{2}{*}{ Capuzzo et $\mathrm{al}^{24}$} & \multirow[t]{2}{*}{2009} & \multirow{2}{*}{$\begin{array}{l}\text { Platinum-based } \\
\text { doublet } \times 4 \\
\text { cycles }\end{array}$} & Erlotinib 150 mg/d & 12.3 weeks & 12.0 & \multirow{2}{*}{$\begin{array}{l}\text { Rash, 9\%; } \\
\text { diarrhea, } 2 \% \\
\text { rash, } 0 \% \\
\text { diarrhea, } 0 \%\end{array}$} & \multirow{2}{*}{$\begin{array}{l}\text { No difference in } \\
\text { global QoL; } \\
\text { time to pain } \\
\text { favored erlotinib }\end{array}$} \\
\hline & & & Placebo & $\begin{array}{c}11.1 \text { weeks } \\
P<.001\end{array}$ & $\begin{array}{c}11.0 \\
P=.0088\end{array}$ & & \\
\hline \multirow[t]{2}{*}{$\begin{array}{l}\text { Miller et } \mathrm{al}^{25} \text { and } \\
\text { Kabbinavar } \\
\text { et } \mathrm{al}^{26}\end{array}$} & 2009 & \multirow{2}{*}{$\begin{array}{l}\text { Platinum-based } \\
\text { doublet and } \\
\text { bevacizumab } \times \\
4 \text { cycles }\end{array}$} & $\begin{array}{l}\text { Bevacizumab } 15 \mathrm{mg} / \mathrm{kg} \\
\text { every } 3 \text { weeks }+ \\
\text { erlotinib } 150 \mathrm{mg} / \mathrm{d}\end{array}$ & 4.76 & 15.9 & $\begin{array}{l}\text { Total, } 44.1 \% \\
\text { rash, } 10.4 \% \\
\text { diarrhea, } 9.3 \%\end{array}$ & \multirow[t]{2}{*}{ NR } \\
\hline & 2010 & & $\begin{array}{l}\text { Bevacizumab } 15 \text { mg/kg } \\
\text { every } 3 \text { weeks + } \\
\text { placebo }\end{array}$ & $\begin{array}{c}3.75 \\
P=.0012\end{array}$ & $\begin{array}{c}13.9 \\
P=.2686\end{array}$ & $\begin{array}{l}\text { Total, } 30.4 \% \\
\text { rash, } 0.5 \% \\
\text { diarrhea, } 0.8 \%\end{array}$ & \\
\hline \multirow[t]{2}{*}{ Pérol et al $^{15}$} & \multirow[t]{2}{*}{2010} & \multirow[t]{2}{*}{ CisG $\times 4$ cycles } & Erlotinib 150 mg/d & 2.9 months & NR & $\begin{array}{l}\text { Total, } 15.5 \% \\
\text { rash, } 9 \% \\
\text { diarrhea, } 0.6 \%\end{array}$ & \multirow[t]{2}{*}{ NR } \\
\hline & & & Observation & $\begin{array}{l}1.9 \text { months; } \\
P=.002\end{array}$ & & $\begin{array}{l}\text { Total, } 2.6 \% \\
\text { rash, } 0 \% \\
\text { diarrhea, } 0 \%\end{array}$ & \\
\hline
\end{tabular}


Based on its efficacy in advanced NSCLC, the epidermal growth factor receptor (EGFR) tyrosine kinase inhibitor (TKI) erlotinib has also been evaluated as switch-maintenance therapy in three randomized phase III studies (Sequential Tarceva in Unresectable Lung Cancer [SATURN], ATLAS, and IFCT-GFCP 0502). Results from the SATURN study were recently published. ${ }^{24}$ This trial evaluated erlotinib maintenance therapy at $150 \mathrm{mg} / \mathrm{d}$ versus placebo in 889 patients without disease progression after treatment with at least 4 cycles of standard first-line platinum-based doublet chemotherapy. Rash (erlotinib 60\% v placebo 8\%) and diarrhea (20\%v3\%) were the most common toxicities, with most reported to be of grade $1 / 2$. Patients in the erlotinib arm had significantly prolonged PFS compared with placebo, in both the unstratified $(12.3 v 11.1$ week; HR, $0.71 ; P<.001)$ and EGFR immunohistochemistry (IHC) -positive study populations (12.3 v 11.1 week; HR, 0.69; $P<.001)$. More importantly, survival was increased in the erlotinib arm, both in the intent to treat population $(12.0 v 11.0$ months; HR, $0.81 ; P=.0088)$ and in the subgroup of patients with wild-type EGFR (11.3 $v 10.2$ months; HR, $0.77 ; P=.0243$ ). Although $72 \%$ of patients in the placebo arm received second-line therapy, only $21 \%$ actually received an EGFR-TKI. Interestingly, subgroup analysis according to EGFR mutation status showed that the majority of the benefit was driven by the patients with wild-type, rather than mutant, EGFR tumors (HR, $0.77 v 0.83) .{ }^{27}$ Biomarker analysis of the SATURN trial evaluated the role of EGFR copy number by fluorescent in situ hybridization (FISH; positive in 48\%), EGFR expression by IHC (positive in $84 \%$ ), $K$-ras mutation (positive in 18\%), and EGFR mutation (positive in $11 \%$ of samples tested). ${ }^{28}$ In this analysis, there was a significant interaction between the presence of EGFR mutation and treatment benefit with erlotinib, in terms of PFS $(P<.001)$.

The ATLAS study compared bevacizumab plus erlotinib with bevacizumab plus placebo in 743 patients with advanced NSCLC without progression after 4 cycles of platinum doublet chemotherapy plus bevacizumab. ${ }^{25}$ ATLAS is therefore unique among these trials, since its design incorporates standard bevacizumab maintenance in both arms. PFS was significantly longer in the combination maintenance group (4.76 v 3.75 months; HR, 0.722; $P=.0012$ ). The 3 - and 6-month PFS rates was $67.7 \%$ and $40.3 \%$ in the erlotinib arm, compared to $53.4 \%$ and $28.4 \%$ for the placebo arm. Not surprisingly, subgroup analysis showed a significant effect on PFS for never smokers treated with maintenance erlotinib (HR, 0.34). Biomarker status was available in 367 of the patients in the trial, and similar to SATURN, evaluated the influence of EGFR IHC (positive in 52\% of available specimens), EGFR FISH (positive in 23.7\%), EGFR mutation (positive in 14\%), and $K$-ras mutation (positive in $25 \%$ ) on PFS. ${ }^{29}$ Patients who were EGFR FISH positive, EGFR mutated, and K-ras wild-type enjoyed the greatest benefit from therapy with erlotinib and bevacizumab in the maintenance setting (HR, $0.66,0.44$, and 0.67 , respectively). OS, which was a secondary end point, showed a nonsignificant 2-month difference in favor of the experimental group (15.9 $v 13.9$ months; HR, $0.9 ; P=.2686)$. The high baseline OS in the bevacizumab arm, the highest reported in maintenance trials, could be due to patient selection, or effect of bevacizumab in the maintenance setting. Potentially, the addition of another maintenance agent does not confer any additional benefit. Alternatively, based on the number of patients randomly assigned and the high survival attained by the bevacizumab only group, the study may not have had the power to detect OS differences. It has to be noted that the study closed after a second interim analysis confirmed the PFS superiority in the erlotinib arm, which limits the interpretation of this posthoc analysis.

The recently reported IFCT-GFPC 0502 compared erlotinib to observation after 4 cycles of cisplatin/gemcitabine. ${ }^{15}$ As mentioned previously, patients were mandated to receive pemetrexed on progression, and indeed a large portion of these patients was treated (pemetrexed, 76.1\%; erlotinib, 3.9\%; and docetaxel, 1.9\%). Baseline characteristics were balanced. Similar to the previous studies, PFS favored the erlotinib group (2.9 v 1.9 months; HR, 0.82; $P=.002)$. OS comparison showed an HR of 0.91 (95\% CI, 0.80 to 1.04$)$ in a preliminary evaluation. Although tissue was submitted for EGFR mutation analysis, results based on mutation status are not currently available. It is interesting, however, that there was no difference in the PFS HR between smokers and nonsmokers in this study (HR 0.79 for smokers and HR 0.88 for nonsmokers).

\section{DISCUSSION}

Optimizing the treatment of advanced NSCLC involves consideration of delivering the most effective therapies, in the right combination, at the right time, while minimizing toxic adverse effects and adverse effects on QoL. Approximately $40 \%$ to $60 \%$ of patients with advanced NSCLC complete 4 cycles of platinum-based chemotherapy without progression or unacceptable toxicity. For these patients, continuation of chemotherapy is a feasible option. The question of how to deliver this additional therapy is the subject of ongoing clinical research.

The US Food and Drug Administration and the European Commission approved pemetrexed in July 2009 as maintenance therapy for patients with nonsquamous histology, for whom disease has not progressed after platinum-based chemotherapy. ${ }^{30,31}$ Of interest, the European Medicines Agency (EMEA) specifically noted that first-line treatment should be a platinum doublet with gemcitabine, paclitaxel, or docetaxel. ${ }^{30}$ Erlotinib as immediate treatment after first-line chemotherapy was also recently approved by the US Food and Drug Administration $^{32}$ and the EMEA. ${ }^{33}$ It has to be noted that although the docetaxel study ${ }^{22}$ was negative, the HR for PFS and OS was fairly consistent with the other switch-maintenance trials (Table 5), suggesting that the lack of statistical significance may relate more to the power of the study than a lack of effectiveness of the strategy.

It is unclear whether the benefit seen in recent maintenance studies is the result of the early institution of noncrossresistant therapy or more practical considerations. Despite strong theoretical rationale, ${ }^{34}$ the planned sequential delivery of noncrossresistant agents has not proven beneficial in advanced NSCLC. ${ }^{35,36}$ A maintenance approach may therefore represent the most effective way to deliver second-line therapy. This is an important point to consider since typically only approximately $60 \%$ of patients are able to receive second-line treatment. The IFCT-GFPC-0502 study is very critical in that respect, with more than $80 \%$ of patients in the control group actually receiving US Food and Drug Administrationapproved treatment. Unfortunately, the trial has limited power to detect survival differences.

A number of additional issues relevant to the delivery of chemotherapy in NSCLC are worth discussing. Who will receive second-line therapy? Results from the docetaxel study show that patients who actually receive chemotherapy in either arm have identical survival at 12.5 months. Although this is a biased analysis, it may suggest that timing is less important than the ability to receive therapy at time of progression. However, is it possible to predict who will receive secondline therapy? Currently, data are only available for the docetaxel study, where factors such as complete response/stable disease (SD), sex, PS, stage IIIB versus IV were examined; however, no characteristic was found that would predict for eventual second-line therapy in the control group.

How should we select patients, who will benefit from maintenance therapy? Results from the docetaxel study suggested that response patients might benefit more than patients with SD. The HR for PFS was 0.47 and 0.81 , while for OS the HR was 0.61 and 1.02 for response and SD patients, respectively. Similarly, the PFS HR in the French study with continuation gemcitabine maintenance favored the 


\begin{tabular}{|c|c|c|c|c|c|}
\hline \multirow[b]{2}{*}{ Characteristic } & \multicolumn{5}{|c|}{ Study } \\
\hline & Fidias $^{22}$ & $\mathrm{JMEN}^{23}$ & SATURN ${ }^{24}$ & ATLAS $^{25}$ & IFCT-GFPC $0502^{15}$ \\
\hline Agent & Docetaxel & Pemetrexed & Erlotinib & Erlotinib + bevacizumab & Erlotinib \\
\hline Control arm treatment & Delayed docetaxel & Placebo & Placebo & Placebo + bevacizumab & Observation \\
\hline No. of patients & 309 & 663 & 889 & 768 & 310 \\
\hline PFS, months & $5.7 \vee 2.7$ & $4.0 \vee 2.0$ & $12.3 \vee 11.1$ weeks & $4.76 \vee 3.75$ & $2.9 \vee 1.9$ \\
\hline PFS for nonsquamous cell histology & & $4.4 \vee 1.8$ & & & \\
\hline Hazard ratio & 0.63 & 0.60 & 0.71 & 0.72 & 0.82 \\
\hline Hazard ratio for nonsquamous cell histology & & 0.47 & & & \\
\hline$P$ & $<.001$ & $<.001$ & $<.001$ & .0012 & .002 \\
\hline Salvage treatment, \% & 63 & 67 & 72 & 55.5 & 81.9 \\
\hline OS, months & $12.3 \vee 9.7$ & $13.4 \vee 10.6$ & $12.0 \vee 11.0$ & $15.9 \vee 13.9$ & NA \\
\hline OS for nonsquamous cell histology & & $15.5 \vee 10.3$ & & & \\
\hline Hazard ratio & 0.80 & 0.79 & 0.81 & 0.9 & 0.91 \\
\hline Hazard ratio for nonsquamous cell histology & & 0.70 & & & \\
\hline$P$ & .085 & .012 & .0088 & .2686 & NA \\
\hline$P$ for nonsquamous cell histology & & .002 & & & \\
\hline
\end{tabular}

responsive patients $(\mathrm{HR}, 0.44 v 0.68)$, while there was no difference in the switch-maintenance approach with erlotinib between response and SD patients (HR, $0.80 v 0.85$, respectively). Subgroup analysis of the pemetrexed study showed improvement only for patients with SD at time of random assignment. ${ }^{37}$ The HR for PFS was 0.53 for responders and 0.48 for SD patients, whereas the HR for OS was 0.90 and 0.68 , respectively. Data from SATURN were concordant with the pemetrexed trial; patients with responsive tumors had an OS HR of 0.94 versus 0.72 for SD. ${ }^{24}$ It is important to note that EMEA approved erlotinib only for patients with SD after 4 cycles of standard platinumbased first-line chemotherapy, although as it can be seen from the above the data is not consistent at all.

Another interesting point comes from the SATURN study, where the benefit in PFS was primarily seen in patients with EGFR mutations, whereas the benefit in OS was driven by EGFR wild-type patients. This suggests that in patients with EGFR mutant tumors, for whom highly effective salvage therapy exists, timing is less important. Unfortunately, such a beneficial effect is not seen with usual chemotherapy.

Results from the pemetrexed study clearly showed benefit only for patients with nonsquamous histology, presumably due to the higher level of thymidylate-synthase in squamous cell cancers. ${ }^{38} \mathrm{Al}-$ though the HR in the SATURN study also favored patients with adenocarcinoma histology, both in terms of PFS (HR $0.60 v 0.76$ for squamous cell cancers) and OS (HR $0.77 v 0.86$ ), benefit from erlotinib was seen in both groups. Similarly, there was no treatment-byhistology interaction in the immediate versus delayed docetaxel study or the IFCT-GFPC-0502 trial for either gemcitabine or erlotinib.

Biomarker analysis has suggested possible patient subgroups, which might derive greater or lesser benefit from treatment with EGFR-TKIs. It is clear that PFS, but not OS, is significantly better in patients with EGFR mutations. In the context of EGFR-mutant lung cancer,studies offirst-lineEGFR-TKIsversusstandard platinum chemotherapy have demonstrated a large benefit in terms of response rate, PFS, and QoL favoring the TKIs. ${ }^{39,40}$ Even in the absence of a survival improvement, we feel that these patients are best served with first-line treatment with an EGFR-TKI, which should not be reserved for second-line or maintenance therapy. Patients with $\mathrm{K}$-ras mutation, however, seem to have less benefit. In the SATURN trial, PFS was statistically significant only for patients with wild-type tumors (HR, 0.70; $P=.0009 v \mathrm{HR}, 0.77 ; P=.2246$ for mutant tumors), although on further analysis there was no interaction with treatment effect for this variable $(P=.95) .{ }^{41}$ Similarly, $K$-ras wild-type status was associated with a PFS HR of 0.67 (95\% CI, 049 to 0.91$)$ in the ATLAS study, compared to a HR of 0.93 (95\% CI, 0.55 to 1.56 ) for mutant tumors. In addition, there is a long line of publications, which show questionable benefit to therapy with EGFR-TKIs for patients with K-ras mutant NSCLC, ${ }^{42-44}$ and in one study, treatment with erlotinib was associated with significantly worse survival in such patients. ${ }^{45}$ Although these data cannot be considered conclusive, a practice favoring treatment with EGFR-TKIs for K-ras wild-type patients is currently the most advisable approach.

Although the IFCT-GFPC 0502 is the only study to include both the switch and continuation-maintenance approaches within the same trial, the two experimental arms were compared separately to the control group, and not to each other. However, the HR for both PFS and preliminary OS analysis appeared to be more robust with continuation chemotherapy compared to switch erlotinib. The question is whether this difference, if real, reflects benefit from the strategy versus the agent used. At this point, all studies with proven OS benefit have followed a switch-maintenance strategy. On the basis of the design of the Pemetrexed and Best Supportive Care Versus Placebo and Best Supportive Care in Non-Small Cell Lung Cancer (JMEN) trial, it is unclear whether the beneficial effect of pemetrexed maintenance extends to patients treated initially with pemetrexed. Several phase III trials are underway to examine this issue. In the Point-Break study, patients are being randomly assigned to either the ECOG 4599 regimen (carboplatin, paclitaxel, and bevacizumab, followed by bevacizumab) or the Patel regimen (carboplatin, pemetrexed, and bevacizumab followed by pemetrexed and bevacizumab). In another important study, patients with SD or responsive disease after 4 cycles 
of cisplatin and pemetrexed are randomly assigned to either pemetrexed or to observation. Lastly, in A Study of Avastin (Bevacizumab) With or Without Pemetrexed as Maintenance Therapy After Avastin in First Line in Patients With Non-Squamous Non-Small Cell Lung Cancer (AVAPERL1), patients are randomly assigned to either bevacizumab alone or bevacizumab and pemetrexed after 4 cycles of induction therapy with cisplatin, pemetrexed, and bevacizumab.

Apart from the ATLAS trial, results of recent maintenance studies do not take into account the use of bevacizumab. Results from a phase III trial (Gynecologic Oncology Group 218) in advanced ovarian cancer examining the use of maintenance bevacizumab were presented in the 2010 ASCO meeting. ${ }^{46}$ Relative to patients treated with chemotherapy alone, the HR for progression or death was $0.908(P=.16)$ for the group treated with first-line chemotherapy/bevacizumab, but without maintenance. In contrast, the HR was $0.717(P<.0001)$ for those patients treated with maintenance bevacizumab. These intriguing results suggest a beneficial antitumor effect of antiangiogenic maintenance therapy, which may translate in other tumor types as well. The Eastern Cooperative Oncology Group is planning a randomized trial of three different maintenance strategies in patients with NSCLC after four cycles of carboplatin, paclitaxel, and bevacizumab: pemetrexed alone, bevacizumab alone, or pemetrexed plus bevacizumab.

What is the most appropriate study end point? Debate on maintenance therapy is, in part, a debate about timing of therapy in NSCLC. Therefore, OS, and not PFS, is the most appropriate end point. Even if a survival benefit is demonstrated, patients often have different priorities, placing greater importance on improvements in QoL. ${ }^{47}$ Older studies occasionally showed worsening in QoL with prolongation of chemotherapy, although such studies often included cisplatin regimens. More recent studies have shown no detriment in QoL when comparing different durations of chemotherapy ${ }^{11}$ or when comparing delayed versus immediate second-line therapy. ${ }^{22,27}$ In the docetaxel study, there was no significant difference between the immediate docetaxel and delayed docetaxel arms with respect to global QoL (improvement: 15.6\% for both arms; worsening: immediate $11.0 \%$ and delayed $18.4 \%$; overall $P=.76$ ). Symptom control data from the SATURN study augment this point: although there was no difference in time to deterioration in QoL by Functional Assessment of Cancer Therapy-Lung in the two arms (HR, 0.96), there was an improvement in time to pain and time to analgesic use in favor of the erlotinib arm (HR, 0.61 and 0.66 , respectively). In the pemetrexed study, drug-related toxicity was greater for the pemetrexed arm, including anemia, fatigue, anorexia, and nausea. However, time to symptom worsening analysis favored pemetrexed maintenance for control of pain $(6.1 \vee 4.6$ months; $P=.041)$ and hemoptysis. ${ }^{23}$

Ultimately, physicians and patients will have to decide on the timing of additional chemotherapy, based on prior treatment tolerance, the expected acute toxicities of the proposed regimen, and potential benefits in terms of survival and symptom control.

With regard to future developments in the treatment of patients with advanced NSCLC, special attention will be paid to the identification of patient subgroups more or less likely to benefit from maintenance therapy, as this approach becomes a new therapeutic option.

\section{AUTHORS' DISCLOSURES OF POTENTIAL CONFLICTS OF INTEREST}

Although all authors completed the disclosure declaration, the following author(s) indicated a financial or other interest that is relevant to the subject matter under consideration in this article. Certain relationships marked with a " $U$ " are those for which no compensation was received; those relationships marked with a "C" were compensated. For a detailed description of the disclosure categories, or for more information about ASCO's conflict of interest policy, please refer to the Author Disclosure Declaration and the Disclosures of Potential Conflicts of Interest section in Information for Contributors.

Employment or Leadership Position: None Consultant or Advisory Role: Panos Fidias, Genentech (C) Stock Ownership: None Honoraria: Panos Fidias, Eli Lilly, Genentech, sanofi-aventis Research Funding: None Expert Testimony: None Other Remuneration: None

\section{AUTHOR CONTRIBUTIONS}

Conception and design: Panos Fidias, Silvia Novello

Collection and assembly of data: Panos Fidias

Data analysis and interpretation: Panos Fidias

Manuscript writing: All authors

Final approval of manuscript: All authors

\section{REFERENCES}

1. Jemal $A$, Siegel $R$, Ward $E$, et al: Cancer statistics, 2008. CA Cancer J Clin 58:71-96, 2008

2. National Comprehensive Cancer Network: Clinical Practice Guidelines in Oncology: Non-small cell lung cancer v. 2.2010. http://www.nccn.org/ professionals/physician_gls/PDF/nscl.pdf

3. Azzoli CG, Baker S Jr, Temin S, et al: American Society of Clinical Oncology Clinical Practice Guideline update on chemotherapy for stage IV non-small-cell lung cancer. J Clin Oncol 27:6251-6266, 2009

4. Sandler A, Gray R, Perry MC, et al: Paclitaxel-carboplatin alone or with bevacizumab for non-small-cell lung cancer. $N$ Engl J Med 355:2542-2550, 2006

5. Pirker R, Pereira JR, Szczesna A, et al: Cetuximab plus chemotherapy in patients with advanced non-small-cell lung cancer (FLEX): An open-label randomised phase III trial. Lancet 373:1525-1531, 2009
6. Soon YY, Stockler MR, Askie LM, et al: Duration of chemotherapy for advanced non-small-cell lung cancer: A systematic review and meta-analysis of randomized trials. J Clin Oncol 27:3277-3283, 2009

7. Lima JP, dos Santos LV, Sasse EC, et al: Optimal duration of first-line chemotherapy for advanced non-small cell lung cancer: A systematic review with meta-analysis. Eur J Cancer 45:601607,2009

8. Scagliotti GV, Parikh $P$, von Pawel J, et al: Phase III study comparing cisplatin plus gemcitabine with cisplatin plus pemetrexed in chemotherapynaive patients with advanced-stage non-small-cell lung cancer. J Clin Oncol 26:3543-3551, 2008

9. Smith IE, O'Brien ME, Talbot DC, et al: Duration of chemotherapy in advanced non-small-cell lung cancer: A randomized trial of three versus six courses of mitomycin, vinblastine, and cisplatin. J Clin Oncol 19:1336-1343, 2001

10. Socinski MA, Schell MJ, Peterman A, et al: Phase III trial comparing a defined duration of ther- apy versus continuous therapy followed by secondline therapy in advanced-stage IIIB/IV non-small-cell lung cancer. J Clin Oncol 20:1335-1343, 2002

11. von Plessen $C$, Bergman $B$, Andresen $O$, et al: Palliative chemotherapy beyond three courses conveys no survival or consistent quality-of-life benefits in advanced non-small-cell lung cancer. Br J Cancer 95:966-973, 2006

12. Belani CP, Barstis J, Perry MC, et al: Multicenter, randomized trial for stage IIIB or IV nonsmall-cell lung cancer using weekly paclitaxel and carboplatin followed by maintenance weekly paclitaxel or observation. J Clin Oncol 21:2933-2939, 2003

13. Brodowicz T, Krzakowski M, Zwitter M, et al: Cisplatin and gemcitabine first-line chemotherapy followed by maintenance gemcitabine or best supportive care in advanced non-small cell lung cancer: A phase III trial. Lung Cancer 52:155-163, 2006

14. Belani CP, Waterhouse DM, Ghazal $H$, et al: Phase III study of maintenance gemcitabine (G) and best supportive care (BSC) versus BSC, following 
standard combination therapy with gemcitabinecarboplatin (G-Cb) for patients with advanced nonsmall cell lung cancer (NSCLC). J Clin Oncol 28: 540s, 2010 (suppl; abstr 7506)

15. Perol M, Chouaid C, Milleron BJ, et al: Maintenance with either gemcitabine or erlotinib versus observation with predefined second-line treatment after cisplatin-gemcitabine induction chemotherapy in advanced NSCLC: IFCT-GFPC 0502 phase III study. J Clin Oncol 28:540s, 2010 (suppl; abstr 7507)

16. Fossella $F$, Pereira JR, von Pawel J, et al: Randomized, multinational, phase III study of docetaxel plus platinum combinations versus vinorelbine plus cisplatin for advanced non-small-cell lung cancer: The TAX 326 study group. J Clin Oncol 21:3016-3024, 2003

17. Shepherd FA, Dancey J, Ramlau $R$, et al: Prospective randomized trial of docetaxel versus best supportive care in patients with non-small-cell lung cancer previously treated with platinum-based chemotherapy. J Clin Oncol 18:2095-2103, 2000

18. Shepherd FA, Rodrigues Pereira J, Ciuleanu T, et al: Erlotinib in previously treated non-small-cell lung cancer. N Engl J Med 353:123-132, 2005

19. Hanna N, Shepherd FA, Fossella FV, et al: Randomized phase III trial of pemetrexed versus docetaxel in patients with non-small-cell lung cancer previously treated with chemotherapy. J Clin Oncol 22:1589-1597, 2004

20. de Marinis F, Grossi F: Clinical evidence for second- and third-line treatment options in advanced non-small cell lung cancer. Oncologist 13:14-20 2008 (suppl 1)

21. Gandara DR, Vokes $E$, Green $M$, et al: Activity of docetaxel in platinum-treated non-small-cell lung cancer: Results of a phase II multicenter trial. J Clin Oncol 18:131-135, 2000

22. Fidias PM, Dakhil SR, Lyss AP, et al: Phase III study of immediate compared with delayed docetaxel after front-line therapy with gemcitabine plus carboplatin in advanced non-small-cell lung cancer. J Clin Oncol 27:591-598, 2009

23. Ciuleanu $T$, Brodowicz $T$, Zielinski $C$, et al: Maintenance pemetrexed plus best supportive care versus placebo plus best supportive care for nonsmall-cell lung cancer: A randomised, double-blind, phase 3 study. Lancet 374:1432-1440, 2009

24. Cappuzzo F, Ciuleanu T, Stelmakh L, et al: Erlotinib as maintenance treatment in advanced non-small-cell lung cancer: A multicentre, randomised, placebo-controlled phase 3 study. Lancet Oncol 11:521-529, 2010

25. Miller VA, $\mathrm{O}^{\prime}$ Connor $\mathrm{P}$, Soh $\mathrm{C}$, et al: A randomized, double-blind, placebo-controlled, phase IIIb trial (ATLAS) comparing bevacizumab (B) therapy with or without erlotinib $(\mathrm{E})$ after completion of chemotherapy with B for first-line treatment of locally advanced, recurrent, or metastatic non-small cell lung cancer. J Clin Oncol 27:407s, 2009 (suppl; LBA8002)

26. Kabbinavar $F$, Miller VA, Johnson BE, et al: Overall survival (OS) in ATLAS, a phase IIlb tria comparing bevacizumab (B) therapy with or without erlotinib (E) after completion of chemotherapy (chemo) with B for first-line treatment of locally advanced, recurrent, or metastatic non-small cell lung cancer (NSCLC). J Clin Oncol 28:15s, 2010 (suppl; abstr 7526)

27. Cappuzzo F, Coudert B, Wierzbicki R, et al: Efficacy and safety of erlotinib as first-line maintenance in NSCLC following non-progression with chemotherapy: Results from the phase III SATURN study. Presented at the 2009 World Lung Cancer Conference, August 1-4, 2009, San Francisco, CA

28. Brugger $\mathrm{W}$, Kim J-H, Hansen $\mathrm{O}$, et al: Biomarker analyses from SATURN, a phase III placebocontrolled study of erlotinib as first-line maintenance therapy for advanced NSCLC. Eur J Cancer 7:559, 2009 (abstr P-9176)

29. Johnson B, Miller $V$, Amler $L$, et al: Biomarker evaluation in the randomized, double-blind, placebocontrolled, Phase IIlb ATLAS Trial, comparing bevacizumab (B)therapy with or without erlotinib (E), after completion of chemotherapy with B for the treatment of locally-advanced, recurrent, or metastatic non-small cell lung cancer (NSCLC). Eur $J$ Cancer 7:5, 2009 (abstr 8LBA)

30. European Medicines Agency: Press Release May 29, 2009. http://www.ema.europa.eu/pdfs/ human/opinion/Alimta_33182709en.pdf

31. US Food and Drug Administration: Pemetrexed injection. http://www.fda.gov/AboutFDA/ CentersOffices/CDER/ucm170660.htm

32. US Food and Drug Administration: Erlotinib. http://www.fda.gov/AboutFDA/CentersOffices/CDER/ ucm209058.htm

33. European Medicines Agency: Press release, March 18, 2010. http://www.ema.europa.eu/pdfs/ human/opinion/Tarcevall_8608010en.pdf

34. Goldie JH, Coldman AJ, Gudauskas GA: Rationale for the use of alternating non-cross-resistant chemotherapy. Cancer Treat Rep 66:439-449, 1982

35. Novello S, Falcone A, Crino L, et al: Randomised multicenter phase II study of two schedules of docetaxel and gemcitabine or cisplatin/gemcitabine followed by docetaxel as first line treatment for advanced non-small cell lung cancer. Lung Cancer 66:327-332, 2009

36. Sculier JP, Lafitte JJ, Lecomte J, et al: A phase III randomised trial comparing sequentia chemotherapy using cisplatin-based regimen and paclitaxel to cisplatin-based chemotherapy alone in advanced non-small-cell lung cancer. Ann Oncol 18:1037-1042, 2007

37. Belani $C P$, Brodowicz $T$, Ciuleanu $T$, et al: Maintenance pemetrexed (Pem) plus best supportive care (BSC) versus placebo (Plac) plus BSC: A randomized phase III study in advanced non-small cell lung cancer (NSCLC). J Clin Oncol 27:407s, 2009 (suppl; abstr CRA8000)

38. Scagliotti G, Hanna N, Fossella F, et al: The differential efficacy of pemetrexed according to NSCLC histology: A review of two phase III studies. Oncologist 14:253-263, 2009

39. Mok TS, Wu YL, Thongprasert $S$, et al: Ge fitinib or carboplatin-paclitaxel in pulmonary adenocarcinoma. N Engl J Med 361:947-957, 2009

40. Maemondo $M$, Inoue $A$, Kobayashi $K$, et al: Gefitinib or chemotherapy for non-small-cell lung cancer with mutated EGFR. N Engl J Med 362:23802388, 2010

41. Brugger $W$, Triller $N$, Blasinska-Morawiec $M$, et al: Biomarker analyses from the phase III placebocontrolled SATURN study of maintenance erlotinib following first-line chemotherapy for advanced NSCLC. J Clin Oncol 27:411s, 2009 (suppl; abstr 8020)

42. Jackman DM, Yeap BY, Lindeman NI, et al: Phase II clinical trial of chemotherapy-naive patients $>$ or $=70$ years of age treated with erlotinib for advanced non-small-cell lung cancer. J Clin Oncol 25:760-766, 2007

43. Pao W, Wang TY, Riely GJ, et al: KRAS mutations and primary resistance of lung adenocarcinomas to gefitinib or erlotinib. PLoS Med 2:e17, 2005

44. Zhu CQ, da Cunha Santos G, Ding K, et al: Role of KRAS and EGFR as biomarkers of response to erlotinib in National Cancer Institute of Canada Clinical Trials Group Study BR. 21. J Clin Oncol 26:4268-4275, 2008

45. Eberhard DA, Johnson BE, Amler LC, et al: Mutations in the epidermal growth factor receptor and in KRAS are predictive and prognostic indicators in patients with non-small-cell lung cancer treated with chemotherapy alone and in combination with erlotinib. J Clin Oncol 23:5900-5909, 2005

46. Burger RA, Brady MF, Bookman MA, et al: Phase III trial of bevacizumab (BEV) in the primary treatment of advanced epithelial ovarian cancer $(\mathrm{EOC})$, primary peritoneal cancer (PPC), or fallopian tube cancer (FTC): A Gynecologic Oncology Group study. J Clin Oncol 28:5s, 2010 (suppl; abstr LBA1)

47. Silvestri G, Pritchard R, Welch HG: Preferences for chemotherapy in patients with advanced non-small cell lung cancer: Descriptive study based on scripted interviews. BMJ 317:771-775, 1998 